\title{
Children's lunchtime food choices following the introduction of food-based standards for school meals: observations from six primary schools in Sheffield
}

\author{
Rebecca Golley, Jo Pearce and Michael Nelson* \\ School Food Trust, Geraldine Hall Suite, Moorfoot, Sheffield S1 4PQ, UK
}

Submitted 17 December 2009: Accepted 4 June 2010: First published online 24 August 2010

\begin{abstract}
Objective: To describe the lunchtime choices and nutritional intake of primaryschool-aged children in England 4 months after the introduction of interim foodbased standards for school lunches.

Design: Cross-sectional $2 \mathrm{~d}$ weighed food records collected in January and February 2007.

Setting: Six primary schools in Sheffield, England.

Subjects: One hundred and twenty-three pupils aged 8-10 years.

Results: Vegetables $(81 \% v, 8 \%)$ and cakes and biscuits $(43 \% v .23 \%)$ were chosen more frequently by pupils consuming a school lunch, while fruit ( $40 \% v$. $36 \%)$, meat products ( $18 \% v .14 \%)$, confectionery $(72 \% v .0 \%)$, savoury snacks (69\% v. 0\%) and drinks not meeting the school food standards (40\% v. $0 \%)$ were chosen more often by pupils eating a packed lunch. Mean energy intake was lower in the school lunch group compared with the packed lunch group (1402 (SD 573) v. 2192 (SD 619), $P=0 \cdot 005$ ). Nutrient density (per MJ energy) was significantly better in school meals for key nutrients including protein $(9 \cdot 8$ (SD $2 \cdot 7)$ v. $6 \cdot 3(\mathrm{sD} 1 \cdot 9) \mathrm{g})$, fat $(7 \cdot 4(\mathrm{SD} 2 \cdot 7)$ v. $10 \cdot 6(\mathrm{sD} 2 \cdot 8) \mathrm{g})$, NSP $(2 \cdot 8(\mathrm{SD} 1 \cdot 3) v .1 \cdot 1$ $(\mathrm{SD} 0 \cdot 4) \mathrm{g})$, vitamin A $(151 \cdot 3(\mathrm{SD} 192 \cdot 8) v \cdot 69 \cdot 1(\mathrm{SD} 55 \cdot 6) \mu \mathrm{g})$, folate $(29 \cdot 6$ (SD 11.6) v. $17 \cdot 0(\mathrm{SD} 7 \cdot 0) \mu \mathrm{g})$, iron $(1 \cdot 3(\mathrm{SD} 0 \cdot 3) v .0 \cdot 9(\mathrm{SD} 0 \cdot 3) \mathrm{mg})$ and zinc $(1 \cdot 1(\mathrm{SD} 0 \cdot 4) v$. $0 \cdot 7(\mathrm{sD} 0 \cdot 3) \mathrm{mg}$ ).

Conclusions: Schools were largely compliant with the interim food-based standards for school meals 4 months after their introduction. Within the context of the new standards, children taking a school lunch are more likely to eat a more nutritious lunch, in terms of less high-fat/salt/sugar foods and nutrient density. The introduction of nutrient-based standards is warranted. Efforts to improve the lunchtime intake of children taking a packed lunch are also required.
\end{abstract}

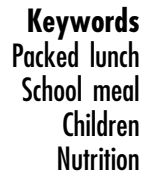

Keywords School meal Children
Primary-school children in England consume 22-33\% of their daily energy and key nutrient intake at lunchtime, which makes an important contribution to their overall $\operatorname{diet}^{(1)}$. Food provided at school can support the establishment of healthy eating habits, and should be consistent with healthy eating messages in the curriculum. Lunch in primary schools in England is usually provided by school caterers ( $43 \%$ school lunch take up in 2006) or by parents as a packed lunch from home ${ }^{(1,2)}$. In the decade before 2006, the food consumed at lunchtime in English schools, whether as a school lunch or packed lunch $^{(1,3-5)}$, was typically high in total and saturated fat, sugar and salt. For example, Rogers et al. ${ }^{(4)}$ found that school meals contained more than $35 \%$ of energy as fat ( $>14 \%$ of energy as saturated fat), with over $20 \%$ of energy derived from sugar. Lunches were also relatively low in fruit and vegetables, as well as key micronutrients such as calcium and iron. The nutritional quality of packed lunches was observed, especially, to be poor, whether assessed alone or compared with school meals ${ }^{(1,5)}$.

In 2001, the Government reintroduced statutory foodbased standards for school meals ${ }^{(6)}$ to ensure that schools provided options at lunchtime that were consistent with the Balance of Good Health Model. By 2004, however, only $23 \%$ of primary schools met all of the statutory foodbased guidelines ${ }^{(3)}$. Moreover, the introduction of the 2001 standards appeared to do little to improve pupils' choice or consumption at lunchtime compared with that reported in $1997^{(7)}$.

In response, the Government invested substantially in school food and introduced new legislation. From September 2006, every primary school in England was required to meet lunchtime food and drink provision guidelines that were much stricter than those introduced 
in 2001. Rather than 'healthier' options being available, 'all' food and drink choices ${ }^{(8)}$ provided at lunchtime were required to be 'healthier'. For example, items such as confectionery and savoury snacks were banned from schools under the new standards ${ }^{(9)}$. These 'interim' food-based standards represented the first step towards a set of foodbased and nutrient-based school food standards effective from September 2008 to ensure that only 'healthier' foods and drinks are provided in schools and that the 'average' school lunch provided a minimum nutrient value ${ }^{(10,11)}$.

Evaluation during the process of implementing new school food standards can indicate whether they are having the desired impact on children's nutrition. In addition, based on previous literature indicating that the majority of children require improvement in their diets (whether they take a school lunch or packed lunch), it is useful to monitor both the school meals that are affected by the new standards and other food being consumed in schools. The aim of the present study is to describe the lunchtime food and drink choices and nutritional intake of primary-school-aged children following the introduction of interim food-based standards for school meals in England in September $2006^{(8)}$. The study also aims to compare the food choices and intake of children eating a school lunch with those taking a packed lunch and evaluate progress towards the forthcoming nutrient-based guidelines.

\section{Experimental methods}

\section{Study design}

A cross-sectional analysis of $2 \mathrm{~d}$ weighed food records that assessed the lunchtime food choices and consumption of children attending six English primary schools in January and February 2007, 4 months after the introduction of the interim food-based standards for school meals.

\section{Study schools}

One hundred Sheffield primary schools within a 10-mile radius of the researchers' base were invited to participate in an intervention study, the details of which are published elsewhere $^{(12)}$. Of the eighteen schools that expressed interest in taking part, six were recruited in line with the study criteria ${ }^{(12)}$.

\section{Sample}

The sample consisted of children aged 8-10 years attending the six study primary schools. To minimise school inconvenience, each school nominated one Year 4 class and one Year 5 class to be observed during the study. Years 4 and 5 were considered old enough to answer questions about their food, were not in transition from infant to secondary school and were not taking part in any government tests during the study period. Parents and pupils in the selected classes were provided with a study information sheet and asked whether the child was willing to take part in the study. Consent to participate was assumed unless a parent or child returned an opt-out form indicating that they did not wish to participate. Within each school, twenty-four pupils were selected at random (stratified for year level, gender, attainment level and whether they were registered as taking a school lunch or packed lunch and excluding those declining participation (2\%) or children with acute or chronic illness based on school records). Of the 144 pupils selected, 136 (94\%) participated in the study.

\section{Data collection and preparation}

Demographic information was collected from school records. This included gender, date of birth, ethnicity, English as an additional language (EAL), the usual type of lunch eaten (i.e. school lunch or packed lunch) and free school meal (FSM) registration. Height (to the nearest $\mathrm{cm}$ ) was measured using Leicester height measures and weight (to the nearest $100 \mathrm{~g}$ ) was measured using calibrated Salter bathroom scales, following standard procedures $^{(13)}$. BMI $\left(\mathrm{kg} / \mathrm{m}^{2}\right)$ was calculated and converted to weight status category using the International Obesity Task Force cut-off points ${ }^{(14)}$.

Food provision in all the schools was assessed against the interim food-based standards for school food using a paper-based version of a menu check list tool ${ }^{(15)}$.

Lunchtime food consumption was assessed using a $2 \mathrm{~d}$ weighed food record completed by a qualified public health nutritionist. For school meals, each child's food and drink choices and leftovers were recorded on two occasions during a single week. At the start of the service, portion weights of all food and drink items available were determined by taking the average of two weighed portions of each food item, measured using Salter food weighing scales (nearest gram). These average portion weights were then applied to school lunch choices that pupils made to determine the average portions of foods or food groups selected across all school meals. The majority of foods in packed lunches were either weighed directly or the weight shown on the packaging was recorded. Where this was not possible, typical portion weights for items were used ${ }^{(16)}$, or weights for commercial items were checked in local supermarkets or via the Internet. Pupils' leftovers for both school food and packed lunches were weighed to the nearest gram. Food intake was calculated by subtracting the leftover food weight from the allocated portion weight. On the twentythree occasions $(1.7 \%)$ that this created negative values, the discrepancy was assumed to be due to variations in portion serving size, and the participants were recorded as having consumed none of that food item.

The Food Standards Agency nutrient databank ${ }^{(17)}$ was used as the source of energy and nutrient data. One hundred and twenty-four new recipe codes were entered, the majority of which were composite school lunch 
recipes based on recipe information provided by the school catering staff. Existing codes were selected for items such as bread, boiled vegetables and potatoes (boiled, baked, etc.) and the food items from packed lunches. Where an item exactly matched the description on the database, the code was used. Where items were similar, based on nutrient profile, a nearest match was used. When items could not be matched to an existing code (mostly new commercial products), a new code was created. All food coding was double checked before data entry. Lunchtime food choice and leftover data were entered into the Statistical Package for Social Sciences statistical software package version $15 \cdot 0$ (SPSS Inc., Chicago, IL, USA) with energy, nutrient and food group data imported from the nutrient databank. Ten per cent of lunchtime choice records were double entered, with a series of checks used to identify errors (e.g. extreme nutrient values). Food group subcategories from the nutrient databank ${ }^{(17)}$ were aggregated in order to develop food group categories reflecting the final food-based standards for school food ${ }^{(10)}$.

The present study was conducted according to the guidelines laid down in the Declaration of Helsinki ${ }^{(18)}$.

\section{Data analysis}

Pupils were categorised as either consuming a 'school lunch' or 'packed lunch'. Twelve children were excluded as they bought a school lunch on one day of measurement and a packed lunch on the other, and one child with no demographic data was also excluded. Data on 123 children were therefore included.

The unit of analysis was the average nutrient content of the two meals consumed by each child. The majority of energy and nutrient variables were normally distributed, and therefore parametric statistics were used. Independent $t$ tests were used to compare energy and nutrient intake by year level and weight status, with no significant differences observed.
Mean weights $(\mathrm{g})$ of selected food groups and the nutrient content/MJ of energy for food and drink items were determined for foods chosen and for foods consumed, and compared by type of lunch (school lunch $v$. packed lunch) using ANOVA, adjusting for sex, school year and school. Mean dietary intake as a proportion of the 2008 nutrient-based standards for school meals ${ }^{(9)}$ was compared by lunch type (using ANOVA). The numbers of children meeting each standard, within each lunch type group, were compared using the $\chi^{2}$ test. All statistical analyses were performed using SPSS version $15 \cdot 0$.

\section{Results}

Lunchtime observations were analysed for 123 children (sixty-three boys and sixty girls; Table 1). Fifty-eight children were classified as taking school meals, with the remaining sixty-five children classified as bringing a packed lunch. There were no significant differences between the school lunch and packed lunch groups in the distribution by sex, year group, percentage of white British or EAL, or in the proportion of pupils who were overweight or obese. There were more pupils with special educational need plans in the school lunch group compared with the packed lunch group ( $40 \%$ v. 20\%). Not surprisingly, there were more pupils in the school lunch group who were eligible for FSM (40\%), although it is interesting to note that $9 \%$ of the packed lunch group were also eligible. All six schools taking part had healthy school status. Three of the schools were catered for by the local authority catering provider and three had independent in-house catering services.

\section{Food choices}

None of the schools met the standard that requires fruitbased desserts to contain $50 \%$ fruit by raw weight (it was more typically between $30 \%$ and $40 \%$ ), and in one school

Table 1 Sample characteristics for all study children and by type of lunch consumed

\begin{tabular}{|c|c|c|c|c|c|c|c|}
\hline & \multicolumn{2}{|c|}{ All pupils ( $n$ 123) } & \multicolumn{2}{|c|}{ School lunch ( $n$ 58) } & \multicolumn{2}{|c|}{ Packed lunch $(n 65)$} & \multirow[b]{2}{*}{$P^{\star}$} \\
\hline & Mean & SD & Mean & SD & Mean & SD & \\
\hline \multirow[t]{2}{*}{ Age (years) } & $9 \cdot 7$ & $0 \cdot 6$ & $9 \cdot 8$ & $0 \cdot 6$ & $9 \cdot 7$ & $0 \cdot 6$ & $0 \cdot 278$ \\
\hline & $n$ & $\%$ & $n$ & $\%$ & $n$ & $\%$ & \\
\hline \multicolumn{8}{|l|}{ Gender } \\
\hline Boys & 63 & $51 \cdot 2$ & 29 & $50 \cdot 0$ & 34 & $52 \cdot 3$ & 0.858 \\
\hline Girls & 60 & $48 \cdot 8$ & 29 & $50 \cdot 0$ & 31 & $47 \cdot 7$ & \\
\hline \multicolumn{8}{|l|}{ Year } \\
\hline 4 & 73 & $59 \cdot 3$ & 32 & $55 \cdot 2$ & 41 & $63 \cdot 1$ & $0 \cdot 462$ \\
\hline 5 & 50 & $40 \cdot 7$ & 26 & $44 \cdot 8$ & 24 & $36 \cdot 9$ & \\
\hline Overweight or obese & 25 & $20 \cdot 3$ & 15 & $25 \cdot 9$ & 10 & $15 \cdot 4$ & $0 \cdot 172$ \\
\hline White British & 111 & $90 \cdot 2$ & 50 & $86 \cdot 2$ & 61 & $93 \cdot 8$ & $0 \cdot 224$ \\
\hline English as additional language & 3 & $2 \cdot 4$ & 2 & $3 \cdot 4$ & 1 & $1 \cdot 5$ & 0.596 \\
\hline Special educational need plans & 36 & $29 \cdot 3$ & 23 & $39 \cdot 7$ & 13 & $20 \cdot 0$ & $0 \cdot 017$ \\
\hline Registered 'eligible' for free school meals & 29 & $23 \cdot 6$ & 23 & $40 \cdot 4$ & 6 & $9 \cdot 2$ & 0.000 \\
\hline
\end{tabular}

${ }^{*} P$ values calculated using the $t$ test for age and the $\chi^{2}$ test for all other variables. 
Table 2 Proportion of children whose lunchtime choices and consumption included a food item from groups included in the 2006 interim food-based standards for school food, and the average amount chosen or consumed (g, mean and SD)

\begin{tabular}{|c|c|c|c|c|c|c|c|c|c|c|c|c|c|c|}
\hline \multirow[b]{3}{*}{ Food group } & \multicolumn{7}{|c|}{ Food chosen } & \multicolumn{7}{|c|}{ Food consumed } \\
\hline & \multicolumn{3}{|c|}{ School lunch ( $n$ 58) } & \multicolumn{3}{|c|}{ Packed lunch $(n 65)$} & \multirow[b]{2}{*}{$P^{\star}$} & \multicolumn{3}{|c|}{ School lunch ( $n$ 58) } & \multicolumn{3}{|c|}{ Packed lunch $(n 65)$} & \multirow[b]{2}{*}{$P^{\star}$} \\
\hline & $\%$ & Mean & SD & $\%$ & Mean & SD & & $\%$ & Mean & SD & $\%$ & Mean & SD & \\
\hline \multicolumn{15}{|l|}{ Allowed (g) } \\
\hline Fruitt & 36 & 31 & 10 & 40 & 188 & 134 & 0.000 & 36 & 20 & 15 & 40 & 137 & 123 & 0.001 \\
\hline Vegetables & 81 & 70 & 25 & 8 & 38 & 19 & 0.027 & 81 & 53 & 27 & 8 & 30 & 23 & $0 \cdot 106$ \\
\hline Oily fish‡ & 0 & $-\boldsymbol{\Phi}$ & - & 2 & 21 & $\ldots$ & $\mathrm{N} / \mathrm{A}$ & 0 & $\ldots$ & $-\sigma$ & 2 & 21 & $-\Phi$ & $\mathrm{N} / \mathrm{A}$ \\
\hline Extra bread§ & 52 & 25 & 14 & $-\Phi$ & $-\Phi$ & $-\Phi$ & $\mathrm{N} / \mathrm{A}$ & 52 & 22 & 12 & $-\boldsymbol{\top}$ & $-\Phi$ & $-\Phi$ & $\mathrm{N} / \mathrm{A}$ \\
\hline Water/healthier drinksII & $-\Phi$ & $-\boldsymbol{\Phi}$ & $-\Phi$ & 17 & 351 & 129 & $N / A$ & 0 & $-\Phi$ & -9 & 17 & 307 & 130 & $N / A$ \\
\hline \multicolumn{15}{|l|}{ Restricted (g) } \\
\hline Other drinks & 0 & $-\Phi$ & $-\boldsymbol{\top}$ & 40 & 350 & 97 & $\mathrm{~N} / \mathrm{A}$ & 0 & $-\Phi$ & $-\Phi$ & 38 & 284 & 123 & $\mathrm{~N} / \mathrm{A}$ \\
\hline Confectionery & 0 & $\ldots$ & - & 72 & 37 & 25 & $\mathrm{~N} / \mathrm{A}$ & 0 & - & - & 72 & 27 & 17 & $\mathrm{~N} / \mathrm{A}$ \\
\hline Savoury snacks & 0 & $-\boldsymbol{\top}$ & $-\Phi$ & 69 & 24 & 4 & $N / A$ & 0 & $-\tau$ & $-\Phi$ & 69 & 20 & 8 & $\mathrm{~N} / \mathrm{A}$ \\
\hline Condiments & 12 & 46 & 0 & 6 & 14 & 6 & 0.000 & 12 & 43 & 9 & 6 & 14 & 6 & 0.007 \\
\hline Meat products & 14 & 79 & 47 & 18 & 37 & 15 & 0.015 & 14 & 57 & 36 & 17 & 28 & 17 & $0 \cdot 102$ \\
\hline Starchy food cooked in oil & 53 & 71 & 18 & 0 & $-\Phi$ & $-\Phi$ & N/A & 53 & 59 & 24 & 0 & $-\Phi$ & $-\Phi$ & $\mathrm{N} / \mathrm{A}$ \\
\hline
\end{tabular}

N/A, statistical test not appropriate, as no observations in one or other group.

${ }^{*}$ ANOVA adjusted for sex and free school meal registration.

tIncludes fruit and fruit-based desserts with content of at least $50 \%$ fruit measured by weight of the raw ingredients.

‡Oily fish was not served on the days on which school lunch choices were measured.

§lt was not possible to identify 'extra' bread in packed lunches.

IIWater was provided on tables for pupils to help themselves. It was not possible to determine how much water was consumed by each pupil.

$\uparrow$ Not possible to calculate mean and SD because there were no observations or too few in either of the lunch type groups.

fruit-based desserts were not served the required twice per week.

Except for the generalised lack of compliance with the standard for fruit-based desserts, the food provided by the school caterers met the 2006 interim food-based standards in all but one school in which condiments were not restricted and starchy foods cooked in oil were provided more than three times in 1 week.

Table 2 shows the percentage of children selecting and/or consuming a food item specified in the 2006 interim food-based standards for school food, together with the average weight $(\mathrm{g})$ of food selected or consumed by those choosing the food. Fruit was chosen by just over one-third of the children, although more frequently by those taking a packed lunch than a school lunch $(40 \%$ and $36 \%$, respectively, $P<0 \cdot 001$ ). Fruit consumption was significantly greater in the packed lunch group, 137 (SD 123) g compared to 20 (SD 15) g, reflecting the larger fruit portion provided/chosen in packed lunches $v$. school meals. In contrast, vegetables were chosen more often in school meals (81\%) than in packed lunches (8\%; $P<0 \cdot 001)$. All of the $81 \%$ of children who had chosen vegetables as part of their school lunch also consumed some vegetables. Those eating the vegetables from a school lunch consumed on average 53 ( $\mathrm{sD} 27$ ) g, which is more than the average 30 (SD 23) g consumed by the $8 \%$ of children in the packed lunch group who actually ate vegetables but not significantly so.

As schools had implemented the 2006 interim foodbased standards, children taking a school lunch were unable to choose any less healthy drinks (drinks not meeting the Government's standards for school food ${ }^{(8)}$ ), confectionery or savoury snacks (only nuts, seeds, fruit or vegetables with no added fat, salt or sugar are allowed in schools). In contrast, $40 \%$ of packed lunches contained a drink that did not meet the food-based standard for school meals. Similarly, none of the children having a school lunch had confectionery or snacks, whereas $72 \%$ of children bringing a packed lunch from home brought confectionery and 69\% brought savoury snacks. Over one-quarter (28\%) of children ate both a confectionery and a snack item from their packed lunch. Under the interim food-based standards, cakes and biscuits may be served only at lunchtime as part of a meal. Forty per cent of school meals contained a food item from the cake and biscuit category compared with $23 \%$ of packed lunches.

\section{Energy and nutrient intake}

The total energy content of foods chosen and actual consumption of energy and carbohydrate were, on average, lower in the school meals group than the packed lunch group (Table 3). The average energy content of school meals chosen was $18 \%$ below the nutrient-based standard, and actual consumption was $36 \%$ below it. The energy content of packed lunches, on the other hand, was $22 \%$ above the standard, and actual consumption was close to the standard (2711 and $2192 \mathrm{~kJ}$, respectively). Thus, packed lunches appeared to provide levels of energy closer to the nutrient-based standards than school meals.

Expressed as nutrient density to adjust for differences in energy intake, Table 3 shows the average nutrient content of school meals and packed lunches per MJ of energy consumed. School meals contained significantly more protein $(P=0 \cdot 001)$, NSP $(P=0 \cdot 005)$, vitamin A 
Table 3 Mean and SD of nutrients chosen and consumed per MJ of energy

\begin{tabular}{|c|c|c|c|c|c|c|c|c|c|c|c|c|c|c|}
\hline & \multicolumn{7}{|c|}{ Food chosen } & \multicolumn{7}{|c|}{ Food consumed } \\
\hline & \multicolumn{2}{|c|}{ All (n 123) } & \multicolumn{2}{|c|}{$\begin{array}{l}\text { School lunch } \\
\quad(n 58)\end{array}$} & \multicolumn{2}{|c|}{$\begin{array}{l}\text { Packed lunch } \\
\quad(n 65)\end{array}$} & \multirow[b]{2}{*}{$P^{\star}$} & \multicolumn{2}{|c|}{ All (n 123) } & \multicolumn{2}{|c|}{$\begin{array}{l}\text { School lunch } \\
\quad(n 58)\end{array}$} & \multicolumn{2}{|c|}{$\begin{array}{l}\text { Packed lunch } \\
\quad(n 65)\end{array}$} & \multirow[b]{2}{*}{$P^{\star}$} \\
\hline & Mean & SD & Mean & $\mathrm{SD}$ & Mean & $\mathrm{SD}$ & & Mean & $\mathrm{SD}$ & Mean & SD & Mean & $\mathrm{SD}$ & \\
\hline Energy intake (kJ) & 2268 & 787 & 1774 & 577 & 2711 & 687 & 0.030 & 1820 & 715 & 1402 & 573 & 2192 & 619 & 0.005 \\
\hline Protein $(\mathrm{g})$ & $8 \cdot 0$ & $2 \cdot 8$ & $10 \cdot 1$ & $2 \cdot 2$ & $6 \cdot 2$ & $1 \cdot 7$ & 0.001 & $8 \cdot 0$ & 2.9 & $9 \cdot 8$ & $2 \cdot 7$ & $6 \cdot 3$ & $1 \cdot 9$ & 0.002 \\
\hline Carbohydrate (g) & $33 \cdot 0$ & $6 \cdot 5$ & $35 \cdot 0$ & $6 \cdot 1$ & $31 \cdot 3$ & $6 \cdot 4$ & $0 \cdot 122$ & $33 \cdot 0$ & $7 \cdot 4$ & $35 \cdot 4$ & $7 \cdot 0$ & $30 \cdot 9$ & $7 \cdot 1$ & 0.123 \\
\hline NMES $(\mathrm{g})$ & $7 \cdot 8$ & $5 \cdot 5$ & $5 \cdot 9$ & 3.5 & $9 \cdot 4$ & $6 \cdot 4$ & 0.007 & $7 \cdot 7$ & $5 \cdot 8$ & $6 \cdot 3$ & $4 \cdot 0$ & $8 \cdot 9$ & $6 \cdot 9$ & 0.061 \\
\hline Fat $(g)$ & $9 \cdot 2$ & $3 \cdot 0$ & $7 \cdot 5$ & $2 \cdot 6$ & $10 \cdot 8$ & $2 \cdot 5$ & 0.020 & $9 \cdot 1$ & $3 \cdot 2$ & $7 \cdot 4$ & $2 \cdot 7$ & $10 \cdot 6$ & $2 \cdot 8$ & 0.028 \\
\hline Saturated fat (g) & 3.5 & $1 \cdot 5$ & $2 \cdot 8$ & 1.5 & $4 \cdot 1$ & $1 \cdot 3$ & 0.080 & $3 \cdot 4$ & $1 \cdot 5$ & $2 \cdot 8$ & 1.5 & $4 \cdot 0$ & $1 \cdot 3$ & 0.091 \\
\hline NSP $(g)$ & $2 \cdot 0$ & $1 \cdot 2$ & $2 \cdot 9$ & $1 \cdot 2$ & $1 \cdot 1$ & $0 \cdot 3$ & 0.005 & 1.9 & $1 \cdot 2$ & $2 \cdot 8$ & $1 \cdot 3$ & $1 \cdot 1$ & 0.4 & 0.005 \\
\hline Sodium (mg) & $309 \cdot 1$ & $85 \cdot 9$ & $287 \cdot 5$ & $87 \cdot 8$ & $328 \cdot 4$ & $79 \cdot 9$ & 0.064 & $318 \cdot 7$ & $94 \cdot 2$ & $293 \cdot 2$ & $98 \cdot 3$ & $341 \cdot 4$ & $84 \cdot 8$ & 0.036 \\
\hline Vitamin A $(\mu \mathrm{g})$ & $121 \cdot 5$ & $152 \cdot 3$ & $181 \cdot 3$ & $200 \cdot 1$ & $68 \cdot 1$ & $49 \cdot 3$ & 0.046 & $107 \cdot 9$ & $144 \cdot 0$ & $151 \cdot 3$ & $192 \cdot 8$ & $69 \cdot 1$ & $56 \cdot 6$ & 0.002 \\
\hline Vitamin C (mg) & $11 \cdot 7$ & $13 \cdot 2$ & $13 \cdot 2$ & $11 \cdot 0$ & $10 \cdot 4$ & $14 \cdot 8$ & $0 \cdot 227$ & $11 \cdot 7$ & $16 \cdot 1$ & $12 \cdot 4$ & $15 \cdot 3$ & $11 \cdot 0$ & $17 \cdot 0$ & 0.391 \\
\hline Folate $(\mu \mathrm{g})$ & $23 \cdot 7$ & $11 \cdot 5$ & $31 \cdot 5$ & $11 \cdot 2$ & $16 \cdot 8$ & $6 \cdot 0$ & 0.002 & $22 \cdot 9$ & $11 \cdot 3$ & $29 \cdot 6$ & $11 \cdot 6$ & $17 \cdot 0$ & $7 \cdot 0$ & 0.002 \\
\hline Calcium (mg) & $106 \cdot 6$ & $42 \cdot 7$ & $102 \cdot 0$ & $40 \cdot 7$ & $110 \cdot 8$ & $44 \cdot 4$ & 0.388 & $110 \cdot 3$ & $44 \cdot 7$ & $104 \cdot 9$ & $42 \cdot 9$ & $115 \cdot 2$ & $46 \cdot 1$ & 0.317 \\
\hline Iron (mg) & $1 \cdot 1$ & 0.3 & $1 \cdot 3$ & 0.3 & 0.9 & $0 \cdot 2$ & 0.009 & $1 \cdot 1$ & 0.4 & $1 \cdot 3$ & 0.3 & 0.9 & 0.3 & 0.018 \\
\hline Zinc (mg) & 0.9 & $0 \cdot 4$ & $1 \cdot 2$ & 0.4 & 0.7 & 0.2 & 0.007 & 0.9 & 0.4 & $1 \cdot 1$ & 0.4 & 0.7 & 0.3 & 0.010 \\
\hline
\end{tabular}

NMES, non-milk extrinsic sugars.

*ANOVA adjusted for pupils' sex, school year and energy (kJ) consumed. Nutrient-based standard for energy is $2218 \mathrm{~kJ}$ although a tolerance of $5 \%$ ( $111 \mathrm{~kJ})$ is allowed as meals are unlikely to contain this exact amount of energy.

Table 4 Percentage of children reaching nutrient-based standards for energy and nutrients by type of lunch for food items chosen and consumed at lunchtime

\begin{tabular}{|c|c|c|c|c|c|c|c|c|c|c|c|c|c|c|}
\hline & \multicolumn{7}{|c|}{ Food chosen } & \multicolumn{7}{|c|}{ Food consumed } \\
\hline & \multicolumn{2}{|c|}{ All $(n$ 123) } & \multicolumn{2}{|c|}{$\begin{array}{l}\text { School lunch } \\
\quad(n 58)\end{array}$} & \multicolumn{2}{|c|}{$\begin{array}{l}\text { Packed lunch } \\
\quad(n 65)\end{array}$} & \multirow[b]{2}{*}{$P^{*}$} & \multicolumn{2}{|c|}{ All $(n$ 123) } & \multicolumn{2}{|c|}{$\begin{array}{l}\text { School lunch } \\
\quad(n 58)\end{array}$} & \multicolumn{2}{|c|}{$\begin{array}{l}\text { Packed lunch } \\
\quad(n 65)\end{array}$} & \multirow[b]{2}{*}{$P^{*}$} \\
\hline & $n$ & $\%$ & $n$ & $\%$ & $n$ & $\%$ & & $n$ & $\%$ & $n$ & $\%$ & $n$ & $\%$ & \\
\hline Energy (kJ) & 12 & $9 \cdot 7$ & $3+$ & $5 \cdot 2$ & 9 & $13 \cdot 8$ & 1.000 & 13 & $10 \cdot 6$ & $3+$ & $5 \cdot 2$ & 10 & $15 \cdot 4$ & 0.082 \\
\hline Protein (g) & 121 & $98 \cdot 4$ & 57 & $98 \cdot 3$ & 64 & 98.5 & 0.134 & 110 & $89 \cdot 4$ & 48 & $82 \cdot 8$ & 62 & $95 \cdot 4$ & 0.037 \\
\hline Carbohydrate (g) & 61 & $49 \cdot 5$ & 18 & $31 \cdot 0$ & 43 & $66 \cdot 2$ & 0.000 & 28 & $22 \cdot 8$ & 5 & $8 \cdot 6$ & 23 & $35 \cdot 4$ & 0.000 \\
\hline NMES $(\mathrm{g})$ & 62 & $50 \cdot 4$ & 40 & $69 \cdot 0$ & 22 & $33 \cdot 8$ & 0.000 & 78 & $63 \cdot 4$ & 47 & $81 \cdot 0$ & 31 & $47 \cdot 7$ & 0.000 \\
\hline Fat (q) & 59 & $47 \cdot 9$ & 48 & 83.0 & 11 & $16 \cdot 9$ & 0.000 & 71 & $57 \cdot 7$ & 51 & $87 \cdot 9$ & 20 & $30 \cdot 8$ & 0.000 \\
\hline Saturated fat $(\mathrm{g})$ & 56 & $45 \cdot 5$ & 46 & $79 \cdot 3$ & 10 & $15 \cdot 4$ & 0.000 & 67 & $54 \cdot 4$ & 47 & $81 \cdot 0$ & 20 & $30 \cdot 8$ & 0.000 \\
\hline NSP $(g)$ & 45 & $36 \cdot 6$ & 34 & $58 \cdot 6$ & 11 & $16 \cdot 9$ & 0.000 & 24 & $19 \cdot 5$ & 18 & $31 \cdot 0$ & 6 & $9 \cdot 2$ & 0.003 \\
\hline Sodium (mg) & 33 & $26 \cdot 8$ & 31 & $53 \cdot 4$ & $2 \S$ & $3 \cdot 1$ & 0.000 & 44 & $35 \cdot 8$ & 37 & $63 \cdot 8$ & 7 & $10 \cdot \overline{8}$ & 0.000 \\
\hline Vitamin A $(\mu \mathrm{g})$ & 65 & $52 \cdot 8$ & 37 & $63 \cdot 8$ & 28 & $43 \cdot 1$ & 0.030 & 45 & $36 \cdot 6$ & 23 & $39 \cdot 7$ & 22 & $33 \cdot 8$ & 0.575 \\
\hline Vitamin C (mg) & 79 & $64 \cdot 2$ & 46 & $79 \cdot 3$ & 33 & $50 \cdot 8$ & 0.001 & 59 & $48 \cdot 0$ & 31 & $53 \cdot 4$ & 28 & $43 \cdot 1$ & 0.281 \\
\hline Folate $(\mu \mathrm{g})$ & 42 & $34 \cdot 1$ & 25 & $43 \cdot 1$ & 17 & $26 \cdot 2$ & 0.058 & 22 & $17 \cdot 9$ & 9 & $15 \cdot 5$ & 13 & $20 \cdot 0$ & 0.639 \\
\hline Calcium (mg) & 77 & $62 \cdot 6$ & 25 & $43 \cdot 1$ & 52 & $80 \cdot 0$ & 0.000 & 62 & $50 \cdot 4$ & 19 & $32 \cdot 8$ & 43 & $66 \cdot 2$ & 0.000 \\
\hline Iron (mg) & 15 & $12 \cdot 2$ & $5+$ & $8 \cdot 6$ & 10 & $15 \cdot 4$ & 0.283 & 7 & $5 \cdot 7$ & $2 \dagger$ & $3 \cdot 4$ & 5 & $7 \cdot \overline{7}$ & 0.445 \\
\hline Zinc (mg) & 24 & $19 \cdot 5$ & 9 & $15 \cdot 5$ & 15 & $23 \cdot 1$ & 0.364 & 14 & $11 \cdot 4$ & 6 & $10 \cdot 3$ & 8 & $12 \cdot 3$ & 0.783 \\
\hline
\end{tabular}

NMES, non-milk extrinsic sugars.

${ }^{*} \chi^{2}$ test.

tFewer than five subjects in at least one cell.

$(P=0 \cdot 046)$, folate $(P=0 \cdot 002)$, iron $(P=0 \cdot 009)$ and zinc $(P=0.007)$ and significantly less non-milk extrinsic sugars (NMES; $P=0 \cdot 007)$ and fat $(P=0 \cdot 020)$ than packed lunches. School meals also contained more vitamin $C$ and less saturated fat and sodium than lunches brought from home, although these were not significant. The average nutrient content per MJ of food consumed followed the same trend as food chosen, although differences between NMES content per MJ of food consumed were no longer significant, while differences in sodium were significantly greater in packed lunches than in school meals.

Table 4 shows the percentage of children in each lunch type group whose average intake met the 2008 nutrient-based standards.* The percentages of children achieving the standards that are minima (e.g. carbohydrate, NSP and the micronutrients) were lower for food consumed than for food chosen or provided because children did not eat all of the food that was chosen by them. For the standards that are maxima (e.g. fat, saturated fat and sodium), the percentages achieving the standards

\footnotetext{
* The nutrient-based standards, developed from the recommendations of the School Meals Review Panel ${ }^{(7)}$, apply to the average provision of food and drink in the dining room at lunchtime, neither to the composition of individual meals nor to the consumption of meals by individual children, but the percentage of individual meals meeting the standards is a useful measure of compliance at the individual level.
} 
were higher for food consumed than for food provided because by eating less food than was on their plate, children were more likely to meet the standard.

Only a small percentage of meals met the standard for energy. This is unsurprising due to the usual variations in meal size and children's consumption. Over $95 \%$ of meals provided the minimum amount of protein recommended. In keeping with the findings in Table 3, a higher percentage of packed lunches than school meals met the standard for carbohydrate $(66 \% v .31 \%, P<0 \cdot 001)$. For NMES $(P<$ $0.001)$, fat $(P<0.001)$, SFA $(P<0.001)$, NSP $(P<0.001)$ and sodium $(P<0 \cdot 001)$, however, a higher proportion of school meals met the standards compared with packed lunches, and this was reflected by consumption $(P=0 \cdot 005$, $0 \cdot 010,0 \cdot 028,0 \cdot 017$ and $0 \cdot 002$, respectively). With the exception of calcium, for which the proportion of pupils meeting the standard was higher in the packed lunch group $(P<0 \cdot 001)$, the lunch types were similar in their adequacy for meeting the micronutrient standards. It is worth noting, however, that a significantly higher percentage of school meals chosen met the standards for vitamin $\mathrm{C}$ and folate, but the amount consumed was inadequate to reach the standard for intake.

\section{Discussion}

The present study describes the food, energy and nutrient content of school lunch and packed lunch choices and consumption in a sample of primary-school children. The data were collected after the introduction of the September 2006 interim food-based standards for school lunch.

Previous studies have shown that before the introduction of the new standards for school meals, neither children who ate school meals nor those who ate packed lunches met healthy eating targets of the Government ${ }^{(4)}$. Nevertheless, the food and nutrient profile of school meals tended to be more favourable than packed lunches $^{(3)}$. The findings presented here support previous observations that school meals are typically healthier than packed lunches ${ }^{(4)}$. In these schools, we do not know whether the same findings would have been observed before the introduction of the 2006 food-based standards; but, subsequent to their introduction, children taking a school lunch were more likely to consume vegetables, but not fruit. Children taking a school lunch were no longer consuming drinks other than water, confectionery or savoury snacks, compared with the majority of children taking a packed lunch. School meals were more nutrient-dense than packed lunches, including key nutrients of concern for children such as iron and zinc. In addition, $50 \%$ or more of children's school lunch choices met the then forthcoming 2008 nutrient-based standards for protein, NMES, fat, saturated fat, NSP and sodium, as well as for vitamins A and C. In contrast, chosen foods in the packed lunch group were less likely to meet the standards for fat, saturated fat, NMES, folate, sodium and NSP.

Only $5 \%$ of the children chose school meals that met the standard for energy, but this is partly due to the way in which the standard itself was developed to reflect average provision rather than the energy content meal by meal. Average consumption of energy is therefore a better measure, and on this basis the average energy consumption in the packed lunch group was closer to the standard for energy than school meals. Energy intakes, of course, need to be evaluated alongside trends in physical activity and energy expenditure so as to address issues concerning overweight and obesity ${ }^{(19)}$. There were no differences in height, weight or BMI between children who ate school meals and packed lunches; therefore, it cannot be said that the energy intake differences between the two groups at lunchtime were responsible for differences in overweight or obesity. The energy content of meals eaten at lunchtime also needs to be put into the context of satisfying children's hunger, and maximising the benefits of the lunchtime meal (as compared to dietary routines that involve grazing on low-nutrient or energy-dense foods throughout the school day). Exploring children's lunchtime food choices in the context of their wider food choices would therefore be useful, and current research in the School Food Trust will address this.

No data on school meals or packed lunches in primary schools in Sheffield are available before the introduction of the standards; therefore, it cannot be argued that the introduction of the food-based standards per se is directly responsible for improvements consistent with the standards. That said, the profile of foods on offer and the nutrient content contrast strongly with the findings from the national study of school meals in primary schools in $2005^{(3)}$. Since the introduction of food-based standards for school lunch, children have been given the opportunity to make more nutritionally sound food choices than in the previous study carried out in 2005, leading to better nutrient density for NMES, fat, NSP, vitamin A, folate, iron and zinc. In contrast, the nutrient intakes from packed lunches observed in the present study were similar to those observed by Rogers et al. ${ }^{(4)}$ earlier this decade. Packed lunches were also inferior in terms of nutrient density per MJ of energy consumed. That the Sheffield school meals are notably better than previous observations is, however, consistent with a possible improvement in school lunch provision following the introduction of the standards. In contrast, there appears to be little change in the nutritional value of packed lunches (explained in part, perhaps, by the absence of a concerted campaign to improve the quality of packed lunches). These conclusions are supported by similar findings in a study of 120 6-11-year-olds in Cornwall surveyed 2 months after the introduction of the interim food-based standards ${ }^{(20)}$.

The food-based standards for school meals restrict the provision of some key sources of fat and sugar in children's 
school diets such as crisps, confectionery and soft drinks. In the present study, children taking a school lunch did not consume confectionery or snacks, whereas $72 \%$ of children bringing a packed lunch brought confectionery, $69 \%$ brought savoury snacks and over a quarter brought both. The high salt, sugar and fat contents of these foods may explain why differences in macronutrients between school meals and packed lunches are greater than differences in micronutrients. The failure of more than $50 \%$ of the school meals, as served, to achieve the standards for carbohydrate, folate, calcium, iron and zinc suggests that the introduction of nutrient-based standards is warranted.

In continuing the transformation of school food, the study results highlight areas for attention. Further refinement of food provision is warranted, particularly increasing the fruit availability and portion size (e.g. fruit-rich desserts). The extent to which children consume the food that they are provided or select is also of interest. The present study was not designed to measure wastage at the level of provision (i.e. between provision and choice), although some anecdotal evidence suggests that wastage may be substantial. Marketing of food to pupils and whole-school food approaches that ensure consistent messages on healthy eating across the school day should help.

The present study has some limitations. First, six primary schools in Sheffield are not nationally representative, and comparisons between the results in the present study and the 2005 national survey cannot be taken to indicate that school food has improved nationally. There was, however, a mix of catering providers, including a large catering organisation with a substantial national presence. Together with a similar-sized study carried out in the south of England, the results do provide some evidence of regional/national change. Second, the sample size is small and focused mainly on pupils in Years 4 and 5 who may not be representative of the whole school. Third, data collection was carried out over $2 \mathrm{~d}$ while the nutrient-based standards for school lunch are calculated for the average meal as provided over the entire menu cycle (which may be $5-25 \mathrm{~d}$ long). The strengths of the present study include the assessment of menu compliance with the interim food-based standards (in addition to food chosen and consumed) and assessment of $2 \mathrm{~d}$ of weighed food records per student, which can be considered a reflection of habitual intake at the group level ${ }^{(21)}$.

Because some parents will continue to provide packed lunches, schools should not ignore strategies to improve the quality of packed lunch provision. A school food policy to achieve consistent provision across all food consumed at school, including food brought from home, would help to ensure that all children benefit from good food at school and support a whole-school approach to healthy eating.

\section{Acknowledgements}

The present study was funded by the School Food Trust, St Paul's Place, Sheffield, UK. The authors have no conflict of interest. M.N., J.P. and R.G. were responsible for the study design, J.P. and R.G. for the data collection and analysis. All authors contributed to the writing of the present paper. The authors thank the Sheffield primary schools and pupils involved for their participation and support of the study, and the Sheffield Food in Schools Group, Local Authority and Healthy Schools Programme. They also thank Lesley Wood for the food category aggregation.

\section{References}

1. Gregory J, Lowe S, Bates CJ et al. (2000) National Diet and Nutrition Survey of Young People Aged 4 to 18 Years. London: The Stationery Office.

2. Nicholas J, Wood L \& Nelson M (2007) Second annual survey of take up of school meals in England. http:// www.schoolfoodtrust.org.uk/UploadDocs/Library/Documents/ second_annual_survey_of_take_up_final.pdf

3. Nelson M, Nicholas J, Suleiman S et al. (2006) School Meals in Primary Schools in England. Research Report RR753. London: Department for Education and Skills.

4. Rogers IS, Ness AR, Hebditch K et al. (2007) Quality of food eaten in English primary schools: school dinners vs packed lunches. Eur J Clin Nutr 61, 856-864.

5. Jefferson A \& Cowbrough K (2004) School Lunch Box Survey. Community Nutrition Group, British Dietetic Association/Food Standards Agency. http://www.food. gov.uk/multimedia/pdfs/lunchbox2004report.pdf (accessed August 2010).

6. Department of Education and Skills (2001) Statutory Instrument 2000 No. 1777. Education (Nutritional Standards for School Lunches) (England) Regulations 2000. London: The Stationery Office.

7. School Meals Review Panel (2005) Turning the Tables: Transforming School Food. Main Report. A report on the development and implementation of nutritional standards for school lunches. http://www.schoolfoodtrust.org.uk/ UploadDocs/Library/Documents/SMRP_Report_FINAL.pdf (accessed August 2010).

8. School Food Trust (2008) A Guide to Introducing the Government's Food-Based and Nutrient-Based Standards for School Lunches, pp. 2.1-2.4. London: School Food Trust; available at http://www.schoolfoodtrust.org.uk/ UploadDocs/Contents/Documents/sft_nutrition_guide_aug08. pdf

9. Department for Education and Skills (2006) Statutory Instrument 2006 No. 2381. The Education (Nutritional Standards for School Lunches) (England) Regulations 2006. London: The Stationery Office.

10. Department for Education and Skills (2007) Statutory Instrument 2007 No. 2359. The Education (Nutritional Standards and Requirements for School Food) (England) Regulations 2007. London: The Stationery Office.

11. Department for Education and Skills (2008) The Education (Nutritional Standards and Requirements for School Food) (England) Regulations 2007 (SI 2007/2359) as amended by the Education (Nutritional Standards and Requirements for School Food) (England) (Amendment) Regulations 2008 (SI 2008/1800). http://www.opsi.gov.uk/si/si2007/ uksi_20072359_en_1, http://www.opsi.gov.uk/si/si2008/ uksi_20081800_en_1 (accessed August 2010). 
12. Golley R, Baines E, Bassett P et al. (2010) School lunch and learning behaviour in primary schools; an intervention study. Eur I Clin Nutr (In the Press)

13. Scientific Advisory Committee on Nutrition (2008) Application of WHO Child Growth Standards in the UK 2007. Report Prepared by the Joint SACN/RCPCH Expert Group on Growth Standards. London: TSO.

14. Cole TJ, Bellizzi MC, Flegal KM et al. (2000) Establishing a standard definition for child overweight and obesity worldwide: international survey. BMJ 320, 1240-1243.

15. The School Food Trust (2006) School Food Checklist. http://www.schoolfoodchecklist.schoolfoodtrust.org.uk/ client/index.aspx (accessed August 2010).

16. Food Standards Agency (2002) Food Portion Sizes, 3rd ed. London: The Stationery Office.

17. Food Standards Agency. NDNS Databank Version 1.32.0. London: FSA.
18. World Medical Association (2008) Declaration of Helsinki Ethical Principles for Medical Research Involving Human Subjects. http://www.wma.net/en/30publications/10policies/ b3/17c.pdf (accessed August 2010).

19. Scientific Advisory Committee on Nutrition (2009) SACN Energy Requirements Working Group Draft Report. http:// www.sacn.gov.uk/pdfs/5nov_sacn_energy_drafting_group_ draft.pdf (accessed August 2010).

20. Rees GA, Richards CJ \& Gregory J (2008) Food and nutrient intakes of primary school children: a comparison of school meals and packed lunches. J Hum Nutr Diet 21, 420-427.

21. Nelson M \& Bingham S (1997) Assessment of food consumption and nutrient intake. In Design Concepts in Nutritional Epidemiology, pp. 123-169 [BM Margetts and $\mathrm{M}$ Nelson, editors]. New York: Oxford University Press. 